\title{
Liquidity-Profitability Trade-Off: A Panel Study of Listed Non-Financial Firms in Ghana
}

\author{
Yusheng Kong1, Mohammed Musah ${ }^{2}$, Stephen Kwadwo Antwi² \\ 1Professor, ${ }^{2} \mathrm{PhD}$ Candidates \\ 1, 2School of Finance and Economics, Jiangsu University, Zhenjiang, Jiangsu, China
}

\begin{abstract}
How to cite this paper: Yusheng Kong | Mohammed Musah | Stephen Kwadwo Antwi "Liquidity-Profitability Trade-Off: A Panel Study of Listed Non-Financial Firms in Ghana" Published in International Journal of Trend in Scientific Research and Development (ijtsrd), ISSN: 24566470, Volume-3 | Issue-4, June 2019, pp.1086-1099, URL: https://www.ijtsrd.c om/papers/ijtsrd25 068.pdf

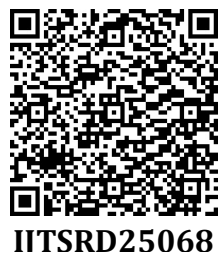

Copyright (c) 2019 by author(s) and International Journal of Trend in Scientific Research and Development Journal. This is an Open Access article distributed under the terms of the Creative Commons

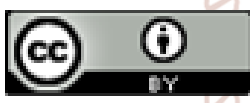
Attribution License (CC BY 4.0) (http://creativecommons.org/licenses/ by $/ 4.0$ )

\section{ABSTRACT}

This study sought to explore the trade-off between liquidity and the profitability of non-financial firms listed on the Ghana Stock Exchange (GSE). A panel data extracted from the audited and published annual reports of fifteen (15) selected firms for the period 2008 to 2017 was used for the study. In the study, liquidity was surrogated by the Cash Flow Ratio (CFR) and the Cash Ratio (CaR), whilst profitability was proxied by Return on Capital Employed (ROCE). After undertaken some diagnostic and specification tests to address the basic assumptions of the Classical Linear Regression Model (CLRM), the study uncovered that, cash flow ratio had a significantly positive effect on the firms' profitability as measured by ROCE $[\beta=0.1050416,(\mathrm{p}=0.038)<0.05]$, but the cash ratio had an insignificantly negative influence on the firms' profitability as measured by ROCE $[\beta=-0.0805403,(p=0.306)>0.05]$. It was further discovered that, the cash flow ratio and the cash ratio had a combined significant effect on the firms' profitability as measured by ROCE [Wald chi2(1)=7.43, $(p=0.0244)<0.05]$. In order to ensure continuous survival and success, the firms should not play with the issue of liquidity management. The entities are expected to maintain an optimal liquidity level that will be capable of performing the 'twin' role of meeting their financial obligations and at the same time maximizing their shareholders' wealth. This optimal liquidity level could be obtained if the establishments are to meet the standards set by the Ghana Stock Exchange (GSE). Adhering to these standards will help the firms to reduce the cases of financial distress. In other words, the firms should keep an adequate level of liquidity that will not portend their going concern status, and yet allow them to make ample returns on their investments. Thus, the firms should strike a balance (trade-off) between their liquidity and profitability. Also, surplus liquidity and inadequate liquidity are two financial ailments that can simply wear down the firms' profitability. Therefore, the establishments must embrace liquidity management in their attempt to optimize profitability. This could be attained if the firms lessen the amounts they hold in cash and focus more on investments so that, they could gain higher returns rather than tying them down in idle cash. From the perspective of theory, the outcome of this study is in tandem with that of prior studies by bringing to light the effect of liquidity on firms' financial performance as measured by ROCE. The firms should therefore inculcate into their decisions the findings of this study so as to meet their operational and expansion needs, as well as the desires of their shareholders.

KEYWORDS: Non-financial firms, liquidity, profitability, trade-off, Ghana.

\section{INTRODUCTION}

Profitability and liquidity are two key issues in corporate finance literature (Niresh, 2012). According to Moffatt (2017) and Kostohryz (2013), liquidity is the ability of firms to meet commitments when they fall due without incurring unacceptable losses. Mueller (2018) also viewed liquidity as the availability of cash and cash equivalents to meet shortterm operational needs of firms. As indicated by Onyekwelu, Chukwuani and Onyeka (2018), Ayu, Zuraida and Mulia (2018), Mohd and Asif (2018), Raykov (2017), Abubakar, Sulaiman and Haruna (2018), Lyndon and Paymaster (2016), Syed (2015), Bragg (2018), Ejike and Agha (2018) and Burke (2019), the types of assets held by corporations and the ease by which those assets could be easily turned into cash indicate how liquid the assets are. For instance, stocks and bonds are termed liquid assets because they can be turned into cash within minutes or hours. However, assets like land, buildings, equipment among others can take days, months or years before they can be converted into cash (Onyekwelu, Chukwuani \& Onyeka, 2018; Ayu, Zuraida \& Mulia, 2018; Mohd \& Asif, 2018; Raykov, 2017; Abubakar, Sulaiman \& Haruna, 2018; Lyndon \& Paymaster, 2016; Syed, 2015; Bragg, 2018; Ejike \& Agha, 2018 \& Burke, 2019).

Profitability on the other hand, is the difference between revenues and expenses over a period of time (usually one year) (Sandhar \& Janglani, 2013). Ajanthan (2013) also 
viewed profitability as the ability of establishments to make returns from all their undertakings. According to the author, profitability indicates how management can make value by efficiently employing all available resources at their disposal. Put simply, profitability is an assessment of management's capacity to generate returns on firms' resources. Low returns therefore suggest that, management did not efficiently put the firms' resources into good use, and investors will be reluctant to invest (Ajanthan, 2013).

According to Peavler (2017), Mueller (2018) and Ally (2017) creditors and investors often use liquidity indicators to measure how well businesses are performing. This is because, creditors are primarily concerned with firms' ability to repay their debts, assuch, they would want to see if there is enough cash and cash equivalents to meet the current portions of their investments. Investors on the other hand, are typically more concerned with the overall health of entities and how they can increase their performance in the future (Peavler, 2017; Mueller, 2018; and Ally, 2017). Enlightening further, Peavler (2017), Mueller (2018) and Ally (2017) indicated that, companies that struggle with liquidity usually have difficulties in growing and increasing their performance. This is because, they do not have shortterm funding available, implying, the firms have failed to efficiently generate revenues from their assets to meet their current obligations (Peavler, 2017; Mueller, 2018; and Ally, 2017).

As postulated by Olagunju, Adeyanju and Olabode (2011), liquidity helps firms to avoid a situation where they will be forced to liquidate with its attendant problems of selling assets at distressed prices and extra fees paid to lawyers, trustees in bankruptcy and liquidators on liquidation. However, Ben-Caleb, Olubukunola and Uwuigbe (2013) and Kesseven (2006) cautioned that, firms' too much focus on liquidity will be at the expense of their profitability. As such, Panigrahi (2013) posited that, liquidity should be well managed by body corporates. To the author, managing liquidity has to do with the avoidance of illiquidity (which is very detrimental as it creates a bad corporate image, makes creditors lose confidence, leads to high-cost of emergency borrowing, result in unnecessary legal battles or even liquidation of firms) and the avoidance of excessive liquidity (which leads to high carrying costs, missed financial opportunities due to inflation, and careless financial decisions that might inversely affect corporate profitability).

The above indicates that, liquidity should neither be too high nor too low as a well monitored minimum level of liquidity at a calculated risk is always good for firms' better performance. This study therefore sought to examine the trade-off between liquidity and the profitability of nonfinancial firms listed on the Ghana Stock Exchange (GSE). Specifically, the study sought to explore the effect of cash flow ratio on the firms' profitability as measured by ROCE; find out the effect of cash ratio on the firms' profitability as measured by ROCE; and to assess the combined effect of cash flow ratio and the cash ratio on the firms' profitability as measured by ROCE. Findings of this study will help management in decisions that relate to the determination of an acceptable liquidity level that will be of benefit to firms. More prominently, this study will add to the existing pool of literature on liquidity and its influence on firms' financial performance. It is hoped that, the outcome of this study will be appreciated by academicians, who may discover useful research gaps that may arouse their interest for further studies. The rest of the study is organised as follows; section two presents literature that supports the topic understudy; whilst section three concentrates on the research methodology and model specification. In the fourth section, empirical results are outlined; whilst the fifth section presents discussions and tests of hypothesis. The sixth section finally presents the study's conclusion and policy implications.

\section{REVIEW OF RELATED LITERATURE}

This section first presents theoretical reviews on the link between liquidity and firms' financial performance. Secondly, empirical findings on the interactions between liquidity and firms' financial performance are brought to light. Thirdly, formulated hypothesis that governed the study's conduct are outlined, whilst a conceptual framework showing the connection between the variables understudy is finally presented.

\subsection{Theoretical Reviews}

Liquidity is the capacity of an establishment to defray its short-term financial obligations in a timely manner (Raykov, 2017; Abubakar, Sulaiman \& Haruna, 2018; Lyndon \& Paymaster, 2016; Syed, 2015; Bragg, 2018; Ejike \& Agha, 2018; and Burke, 2019). High volumes of available cash implies, businesses are in a position to honor their financial obligations when they fall due without a default (Raykov, 2017; Abubakar, Sulaiman \& Haruna, 2018; Lyndon \& Paymaster, 2016; Syed, 2015; Bragg, 2018; Ejike \& Agha, 2018; and Burke, 2019). Liquidity and its affiliations with corporate financial performance has so many theories, however, this study was built on the trade-off theory of liquidity. Salaju and Kumar (2012), Puneet and Parmil (2012) and Garcia and Martinez (2007) viewed liquidity and profitability as dual economic expressions at the tail ends of a thread, where a movement in the direction of one point inevitably means, a drive away from the other. In other words, the two are in a trade-off position.

According to the trade-off hypothesis of liquidity, firms target an ideal level of liquidity to bring into balance the costs and benefits of handling cash (Orshi, 2016). The costs of handling cash comprises of the minimal rate of return on current assets as a result of liquidity premium and possible tax burdens; whilst the benefits of keeping cash are that, firms spare exchange costs to raise reserves and do not ought to settle resources to meet commitments; and firms can utilize liquid resources to fund their undertakings if other means of finance are in shortage (Orshi, 2016). According to the trade-off hypothesis, firms with an increased level of leverage draw high cost in paying back the obligation hence hindering financial viability. It thus become tedious for such corporations to obtain other means of finance (Salaju \& Kumar, 2012; Puneet \& Parmil, 2012; Garcia \& Martinez, 2007; Lamberg \& Valming, 2009; and Dash \& Hanuman, 2008). Holding cash at that point, becomes an issue for both smaller and larger firms. Firms therefore need a balance between liquidity and profitability in order to have an ideal level of liquid resources (Samiloglu \& Demirgunes, 2008; Raheman \& Nasr, 2007; Akella, 2006; and Lazaridiss \& Tryfonidis, 2005).

\subsection{EMPIRICAL REVIEWS}

Ashutosh and Gurpreet (2018) analyzed the financial performance of sugar mills in Punjab. Panel data from both 
co-operative and private sugar mills for the period 2003-04 to 2013-14 was adopted for the study. From the study's multivariate regression analysis, liquidity measured by the current ratio and the quick ratio had an insignificant influence on the profitability of private sugar mills in the Punjab sugar industry. Bilal, Khan, Tufail and Ul Sehar (2013) explored the profitability determinants of the insurance sector in Pakistan. Panel data from 31 firms covering the period 2006 to 2011 was used for the study. From the study's fixed effects model, liquidity was not a significant determinant of the firms' profitability.

Rizwan (2016) studied the influence of liquidity management on the profitability of listed firms in Pakistan. Data from 64 non-financial firms listed on the Karachi Stock Exchange (KSE) 100 Index for the period 2006 to 2011 was used for the study. From the study's multivariate regression analysis, liquidity measured by the current ratio and the cash conversion cycle had a significantly positive effect on the firms' profitability as measured by ROA, but liquidity proxied by the quick ratio and the cash ratio had insignificant influence on the firms' ROA. Ofoegbu, Duru and Onodugo (2016) studied the effect of liquidity on the profitability of pharmaceutical companies in Nigeria. Secondary data from the annual reports and the financial statements of some listed pharmaceutical companies for the period 2000 to 2011 was used for the study. From the study's multiple regression analysis, liquidity ratio had a significantly positive influence on the firms' financial performance as measured by ROA.

Swagatika and Ajaya (2018) explored the determinants of profitability in Indian manufacturing firms. Data covering the pre and post crisis periods from the year 2000 to 2015 was used for the study. From the study's results, liquidity had a significantly positive influence on the firms' profitability as measured by ROA and NPM. Shaheen, Muhammad, Muhammad, Mudasar and Muhammad (2015) examined the effect of liquidity on the profitability of the Pakistani sugar sector. Secondary data extracted from the annual reports of listed sugar mills for the period 2007 to 2012 was employed for the study. From the study's multivariate regression estimates, liquidity had a significantly positive influence on the firms' profitability. In Sri Lanka, Pratheepan (2014) delved into the profitability determinants of 55 manufacturing companies listed on the Colombo Stock Exchange for the period 2003 to 2012. From the study's panel data analysis, liquidity was not a significant determinant of the firms' profitability as measured by ROA.

Batchimeg (2017) conducted a research to examine the determinants of the financial performance of firms listed on the Mongolian Stock Exchange (MSE) for the period 2012 to 2015. Panel data from 100 listed Joint Stock Companies (JSC) from six (6) major sectors in the Mongolian economy was employed for the study. From the study's regression results, liquidity was not a significant determinant of the firms' financial performance as measured by Return on Assets (ROA), Return on Equity (ROE) and Return on Sales (ROS). Ali, Mahmoud, Fadi and Mohammad (2018) conducted a study to examine firm-specific and macroeconomic factors that affected the performance of industrial and service firms listed in Jordan. Panel data for the period 2007 to 2016 was employed for the study. From the study's regression estimates, liquidity proxied by the Current Ratio (CR) had a significantly positive influence on the firms' financial performance as measured by ROA.

Hamidah and Muhammad (2018) studied the influence of leverage, liquidity and profitability on the performance of companies in Malaysia. Data obtained from 21 companies for the period 2010 to 2014 was employed for the study. From the study's multiple regression analysis, liquidity had a significantly positive influence on the firms' financial performance. Maja, Ivica and Marijana (2017) examined the influence of age on the performance of firms in the Croatian food industry. A dynamic panel data from 956 firms operating in the Croatian food sector for the period 2005 to 2014 was used for the study. From the study's regression analysis, the control variable liquidity, had a significantly adverse effect on the firms' performance.

Mehmet and Mehmet (2018) examined the influence of financial characteristics on the profitability of energy firms listed on Borsa Istanbul Stock Exchange. Quarterly (2008:Q1-2015:Q4) panel data of 10 quoted energy firms was employed for the study. From the study's multiple regression analysis, liquidity ratio had a significantly positive effect on the firms' profitability as measured by ROA. Isik (2017) researched on the profitability determinants of real sector firms listed on the Borsa Istanbul Stock Exchange. Panel data from 153 listed firms for the period 2005 to 2012 was used for the study. From the study's findings, liquidity level was a significant determinant of the firms' profitability as measured by ROA. Kanga and Achoki (2017) examined the impact of liquidity on the financial performance of agricultural firms listed on the Nairobi Securities Exchange (NSE). Secondary data extracted from the audited annual reports of listed agricultural companies for the period 2003 to 2013 was adopted for the study. From the study's pooled ordinary least squares regression analysis, liquidity had a significantly positive influence on the firms' financial performance as measured by ROA and ROE.

Mohammed, Muhammad and Imran (2015) explored the connection between liquidity and the profitability of firms listed on the Saudi Stock Exchange (Tadawul). Data from the audited annual reports of 99 listed non-financial firms for the period 2008 to 2012 was employed for the study. From the study's regression output, liquidity measured by the current ratio had a significantly positive influence on the firms' ROA, but liquidity measured by the quick ratio and the cash ratio had an insignificant influence on the firms' ROA. The study further disclosed that, liquidity measured by the current ratio, quick ratio and the cash ratio had an insignificant effect on the firms' profitability as measured by ROE. Derbali (2014) examined the determinants of the financial performance of insurance companies in Tunisia. Panel data from eight (8) life insurance companies for the period 2005 to 2012 was employed for the study. From the study's multiple regression output, liquidity was not a significant predictor of the firms' financial performance. Doğan and Topal (2016) studied factors that explained the profitability of 136 Turkish manufacturing firms listed on the Borsa Istanbul Stock Exchange for the period 2005 to 2012. From the study's pooled OLS regression results, liquidity was weakly related to the firms' ROA. Gonga and Sasaka (2017) examined the determinants of the financial performance of 55 licensed insurance firms in Nairobi County. Data from both primary and secondary sources was 
employed for the study. From the study's findings, liquidity had an insignificantly positive impact on the firms' financial performance.

\subsection{Hypothesis Development}

A statistical hypothesis test is a method of making statistical decisions using data; it is sometimes called confirmatory analysis (Hari, 2011). Hypothesis testing tells whether the proof for rejecting a null hypothesis is reliable or not (Schick \& Vaughn, 2002). According to Schick and Vaughn (2002), Patricia and Hassan (2006) and Patricia and Nandhini
(2013), a statistically significant hypothesis or result is considered not to have occurred by chance. Based on the reviews of prior literature, the following hypothesis were formulated for testing;

$\mathrm{H}_{1}$ : Cash Flow Ratio (CFR) has a significant effect on the firms' profitability as measured by ROCE.

$\mathrm{H}_{2}$ : Cash Ratio (CaR) has a significant effect on the firms' profitability as measured by ROCE.

$\mathrm{H}_{3}$ : Cash Flow Ratio (CFR) and the Cash Ratio (CaR) have a combined significant effect on the firms' profitability as measured by ROCE.

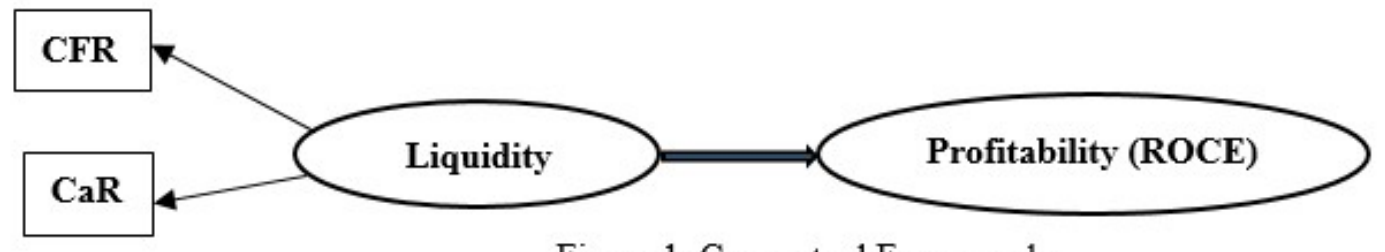

Figure 1: Conceptual Framework

\section{RESEARCH METHODOLOGY}

Howell (2013) defined research methodology as the general research strategy that outlines the way in which research is to be undertaken and among other things, identifies the methods to be used in it. According to the author, these methods define the means or modes of data collection or, sometimes, how a specific result is to be calculated. This aspect of the study presents the research methodology. The methodology covers the data source, diagnostic and specification tests, measurement of study variables, model specification and estimation and the empirical analysis procedure.

\subsection{Data Source}

All non-financial firms that listed and traded their shares on the Ghana Stock Exchange (GSE) for the period 2008 to 2017 formed the study's target population. The purposive or selective sampling technique was employed in choosing the study's sample. As indicated by Crossman (2018), purposive sampling is a non-probability sampling technique in which a sample is selected based on the characteristics of a population and the goal of a study. The purposive sampling technique was used because it was flexible and met multiple needs and interests of the researchers. The technique was also used because it produced a sample that was representative of the entire population (Black, 2010; and Saunders, Lewis \& Thornhill, 2012). The Ghana Oil Company Ltd, Total Petroleum Ghana Ltd, Starwin Products Ltd, Camelot Ghana Ltd, Aluworks Ltd, Clydestone Ghana Ltd, African Champion Industries Ltd, Benson Oil Palm Plantation Ltd, Fan Milk Ltd, Guinness Ghana Breweries Ltd, Unilever Ghana Ltd, PZ Cussons Ghana Ltd, Produce Buying Company Ltd, Mechanical Lloyd Company Ltd and Sam Woode Ltd were the firms that were used for the study. These firms were used because, they were actively operational during the study period and all their financial statements were up to date. The firms totaling fifteen (15), represented $36.59 \%$ of the total number of listed firms or $53.57 \%$ of the total number of non-financial firms listed on the Ghana Stock Exchange (GSE). A balanced panel data extracted from the audited and published annual reports of the firms was employed for the study. The annual reports comprised of the comprehensive income statement, statement of financial position, statement of cash flows, statement of changes in equity and notes to the accounts. These annual reports were obtained from the official website of the Ghana Stock Exchange (GSE). Data from the Ghana Stock Exchange (GSE) was depended upon because, the GSE contains the most comprehensive and reliable data for all its listed firms, and have been updating and validating the annual reports of the firms.

\subsection{Diagnostic and Specification Tests}

Performing linear regressions could not automatically give reliable results on the variables understudy. To bring out reliable outcomes, it was imperative for the researchers to ensure that, some basic assumptions of the Classical Linear Regression Model (CLRM) were met. The basic assumptions that were considered comprised of (1) linearity in parameters, (2) homoscedasticity of the error terms, (3) no perfect multi-collinearity between the explanatory variables, (4) no autocorrelation of the error terms, (5) correct specification of the regression model, and (6) normality of residuals. Since outliers impact on regression results in panel data substantially (Hair, Black, Babin \& Anderson, 2013; Kohler \& Kreuter, 2008), the regression models were tested for the influence of multivariate outliers in addition to the above five (5) assumptions. Table 1 provides a summary of the various assumptions, the tests conducted and their corresponding outcomes, as well as corrective mechanisms undertaken in case of any violations.

Table 1: Summary of Diagnostic and Specification Tests

\begin{tabular}{|l|l|l|l|}
\hline \multicolumn{1}{|c|}{ Assumption } & \multicolumn{1}{|c|}{ Diagnostic/Specification Test } & Result & \multicolumn{1}{c|}{ Countermeasure } \\
\hline $\begin{array}{l}\text { 1. No perfect multi- } \\
\text { collinearity } \\
\text { Between the explanatory } \\
\text { variables }\end{array}$ & $\begin{array}{l}\text { 1. Correlational matrix } \\
\text { 2. Variance Inflation Factor (VIF) and degree } \\
\text { of Tolerance (1/VIF) }\end{array}$ & Fulfilled & - \\
\hline 2. Linearity in parameters & $\begin{array}{l}\text { 1. Harvey \& Collier (1977) test for } \\
\text { linearity }\end{array}$ & Fulfilled & - \\
\hline
\end{tabular}


International Journal of Trend in Scientific Research and Development (IJTSRD) @ www.ijtsrd.com eISSN: 2456-6470

\begin{tabular}{|c|c|c|c|}
\hline 3. Normality of residuals & $\begin{array}{l}\text { 1. Shapiro and Wilk (1965) test for } \\
\text { data normality }\end{array}$ & Violated & $\begin{array}{l}\text { Adoption of a more } \\
\text { generalized or robust } \\
\text { regression estimator }\end{array}$ \\
\hline $\begin{array}{l}\text { 4. Homoscedasticity of the } \\
\text { error terms. }\end{array}$ & $\begin{array}{l}\text { 1. Breusch and Pagan (1979) and Cook and } \\
\text { Weisberg (1983) test for } \\
\text { heteroscedasticity. }\end{array}$ & Violated & $\begin{array}{l}\text { Adoption of robust regression } \\
\text { estimator according to Huber } \\
\text { (1967)/White (1980) }\end{array}$ \\
\hline $\begin{array}{l}\text { 5. No autocorrelation of } \\
\text { the error terms }\end{array}$ & $\begin{array}{l}\text { 1. The Durbin and Watson (1950) } \\
\text { and Durbin and Watson (1951) } \\
\text { test for serial correlation. }\end{array}$ & Violated & $\begin{array}{l}\text { Adoption of robust regression } \\
\text { estimator according to Huber } \\
\text { (1967)/White (1980). }\end{array}$ \\
\hline 6. Outlier effects & $\begin{array}{l}\text { 1. Cox (2007) outliers detecting } \\
\text { technique }\end{array}$ & Violated & $\begin{array}{l}\text { Adoption of robust regression } \\
\text { estimator according to } \\
\text { Huber(1967)/White(1980) }\end{array}$ \\
\hline $\begin{array}{l}\text { 7. Correct specification of } \\
\text { the } \\
\text { regression model. }\end{array}$ & $\begin{array}{l}\text { 1. Durbin (1954), Wu (1973) and Hausman } \\
\text { (1978) model } \\
\text { specification test. }\end{array}$ & Fulfilled & - \\
\hline
\end{tabular}

\subsection{Measurement of Study Variables}

The measurements for liquidity and the firms' financial performance were purely accounting based, deduced from the firms' financial statements (thus, the comprehensive income statement, the statement of financial position, the statement of cash flows, the statement of changes in equity and the notes to the accounts). In this study, the firms' profitability was proxied by Return on Capital Employed (ROCE). The ROCE was calculated as the ratio of net income to the firms' capital employed. On the other hand, liquidity was surrogated by the Cash Flow Ratio (CFR) and the Cash Ratio (CaR). The CFR was computed as the ratio of net operating cash flows to the total current liabilities of the firms, whilst the CaR was calculated as the absolute liquid assets divided by the total current liabilities of the firms. Table 2 presents a detailed summary of the study's variables and their measurements;

Table 2: Measurement of Study Variables

\begin{tabular}{|c|c|c|}
\hline Variable & Proxy & Measurement \\
\hline ROCE & Profitability & Net Income/Capital Employed \\
\hline CFR & Liquidity & Net Operating Cash Flows/Total Current Liabilities \\
\hline CaR & Liquidity & Absolute Liquid Assets/Total Current Liabilities \\
\hline
\end{tabular}

\subsection{Model Specification and Estimation}

The choice of an estimator for the working model depended on the outcome of the model specification test. For the ROCE working model, the Durbin-Wu-Hausman specification test was statistically insignificant at $\alpha=5 \%$. The study therefore rejected the fixed effects model in favor of the random effects model. According to Torres-Reynia (2007), random effects model assumes that an entity's error term is not correlated with the predictors which allow for timeinvariant variables to play a role as explanatory variables. This means, random effects allow for the generalization of inferences beyond the sample used in the model. TorresReynia (2007) put forward the random effects model as;

$$
Y_{i t}=\beta_{1} X_{i t}+\alpha+u_{i t}+\varepsilon_{i t}
$$

Where; $\alpha$ is the intercept; $Y_{i t}$ is $k \times 1$ vector of the response variable representing profitability and proxied by ROCE; $X_{i t}$ is a $k \times 1$ vector of regressors surrogated by the Cash Flow Ratio (CFR) and the Cash Ratio (CR); $\beta_{i t}$ is a $k \times 1$ vector of parameters to be valued; $u_{i t}$ denotes the between-entity error term; $\varepsilon_{i t}$ denotes the within-entity error term; $i$ is the number of cross-section $(i=1,2,3 \ldots \ldots \ldots, N)$; and $t$ is the time period $(t=1,2,3 \ldots \ldots, T)$. With reference to the proxies of the explained and the explanatory variables, equation (1) can be extended as follows;

$$
R O C E_{i t}=\alpha_{i}+\beta_{1} C F R_{i t}+\beta_{2} C a R_{i t}+u_{i t}+\varepsilon_{i t}
$$

Where $\alpha_{i}$ is the intercept; $\beta_{1}$ and $\beta_{2}$ respectively captures the effect of Cash Flow Ratio (CFR) and the Cash Ratio (CaR) on profitability as proxied by ROCE; $u_{i t}$ denotes the betweenentity error term; $\varepsilon_{i t}$ denotes the within-entity error term; $i$ is the number of cross-section; and $t$ is the time period.
It is assumed that CFR and CaR will significantly predict the firms' profitability as measured by ROCE. This implies, the partial slope coefficients are expected to be statistically significantly different from zero. Thus, $\left(\boldsymbol{\beta}_{\boldsymbol{1}}+\boldsymbol{\beta}_{\mathbf{2}} \neq \boldsymbol{0}\right)$ or $\left(\boldsymbol{\beta}_{1}=\boldsymbol{\beta}_{2} \neq \mathbf{0}\right)$ or $\left(\boldsymbol{\beta}_{1}, \boldsymbol{\beta}_{\boldsymbol{2}} \neq \boldsymbol{0}\right)$. This also implies, the firms are expected to be in a trade-off (equilibrium) position where they will be highly liquid and still maximize profitability (Orshi, 2016). Individually, the study projects a positive effect of cash flow ratio and cash ratio $\left(\boldsymbol{\beta}_{\mathbf{1}}, \boldsymbol{\beta}_{\mathbf{2}}>\mathbf{0}\right)$ on the firms' profitability because, establishments with more promising levels of liquidity are more adaptable in terms of giving immediate funding which may result in improved profitability.

\subsection{Empirical Analysis Procedure}

The researchers will first conduct a multi-collinearity test to find out whether the explanatory variables are extremely correlated to each other or not. This test will help the researchers to choose the input variables that will best suit the study. Secondly, because the Classical Linear Regression Model (CLRM) needs the association between the response and the predictor variables to be linear, the researchers will test for linearity in the study's parameters. Thirdly, data abnormality has a lot of consequences, notably amongst them is that, it poses problems for efficiency-that is, the OLS standard errors are no longer the smallest; and the OLS standard errors can be biased-that is, confidence intervals and significance tests may lead to wrong conclusions. The help unravel these concerns, the test for data normality will be conducted. Additionally, the presence of heteroscedasticity is a foremost concern in the application of linear regression analysis because, it could lead to imprecise or misleading inferences. Due to that, the researchers will 
conduct a heteroscedasticity test so as to determine the most suitable regression estimator for the working models. Also, serial or autocorrelation of the errors of working models is consequential because, it makes the OLS estimates to be no longer the Best Linear Unbiased Estimator (BLUE). To help determine the most appropriate regression estimator that could help remedy the issue of serial or autocorrelation in the study's working model, the test for serial correlation will be conducted. Further, observation points that are distant from other observations (outliers) are injurious in regression analysis. This is because, extreme values of observed variables can distort estimates of regression coefficients, which might lead to wrong conclusions or inferences. To help remedy this concerns, the test for outliers in the study's distribution will be conducted. Additionally, one of the key assumptions of the Classical Linear Regression Model (CLRM) is that, a model must be correctly specified. This is because, model misspecification is detrimental as it could yield inaccurate results that might lead to wrong conclusions. In order to come out with the right model that would produce correct estimates resulting in reliable conclusions, the model specification test will be undertaken. After the right model has been specified, the researchers will finally proceed to the multivariate regression analysis. Apart from the linearity test which was accomplished via the R-software package, all the data analysis were conducted through the use of STATA version 15 statistical software package at $\alpha=5 \%(\mathrm{p} \leq 0.05)$. Figure 2 shows the empirical analysis procedure that was followed to achieve the study's goal.

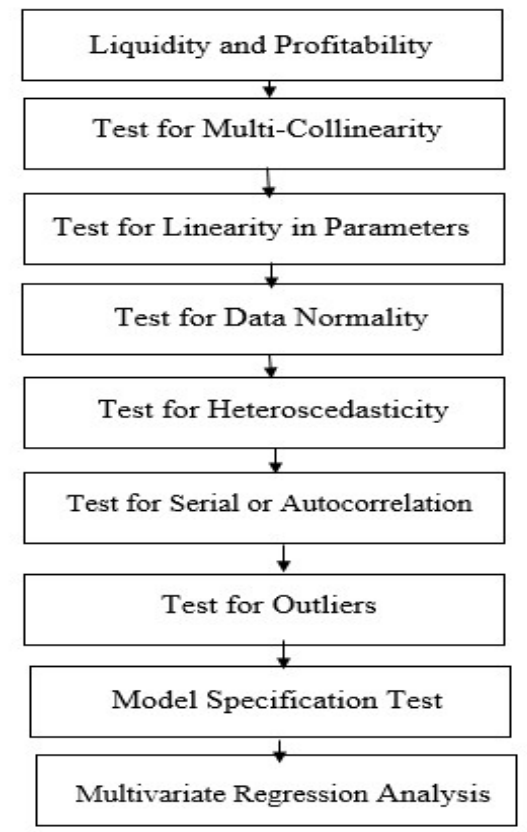

Figure 2: Empirical Analysis Procedure

\section{EMPIRICAL RESULTS}

This aspect of the study presents the study's empirical results. The first five parts of the section bring to light, some diagnostic and specification tests on the assumptions of the Classical Linear Regression Model (CLRM). These tests were undertaken in order to avoid the problems associated with model misspecification and the choice of wrong regressors. The diagnostic and specification tests included the test for multi-collinearity, the test for linearity in parameters, the test for data normality, the test for heteroscedasticity, the serial or autocorrelation test, the test for outliers and the model specification test. The eight part of the section presents descriptive analysis on both the input and out variables, whilst the final part presents regression results on the influence of liquidity on the firms' profitability as measured by ROCE.

\subsection{Test for Multi-Collinearity}

As explained by Kenton (2018), multi-collinearity is the occurrence of high inter-correlations among predictor variables. Multi-collinearity leads to wider confidence intervals and less reliable probability values resulting in skewed or misleading results (Gujarati \& Porter, 2009; Kock \& Lynn, 2012; and O’Brien, 2007). Multi-collinearity was detected through the Variance Inflation Factor (VIF) or the degree of Tolerance (1/VIF), after running the Ordinary Least Squares (OLS) regression with ROCE as the response variable and CFR and CaR as the explanatory variables. The rule of thumb was that, a variable with a VIF greater than 5 $(\mathrm{VIF}>5)$ or a degree of tolerance less than $0.2(1 / \mathrm{VIF}<0.2)$ was considered to be highly collinear with other explanatory variables. From Table 3 , the VIF's of CFR and CaR with their respective degrees of tolerance (1/VIF) indicated that, the variables were not highly correlated with each other [VIF < 5; 1/VIF > 0.2]. This implies, CFR and CaR were fit to be used together in the working model

\section{Table 3: VIF and Tolerance Test}

\begin{tabular}{|c|c|c|}
\hline Variable & VIF & $1 /$ VIF \\
\hline CaR & 2.92 & 0.341969 \\
\hline CFR & 2.92 & 0.341969 \\
\hline Mean VIF & 2.92 & \\
\hline
\end{tabular}

\subsection{Test for Linearity in Parameters}

Damon (2017), Evans (2010), Kolts (2005) and Stewart (2008) explained linearity as a property of mathematical relationship or a function, where two variables $X$ and $Y$ could be graphically represented as a straight line. Gujarati and Porter (2009) also explained linearity in two ways: Firstly, linearity is where the conditional mean value of the output variable is a linear function of the input variable (s) (thus, the $X^{\prime}$ s appear with a power of 1 ); and secondly, linearity is where the conditional mean of the explained variable is a linear function of the parameters or the partial slope coefficients $\left(\beta^{\prime} s\right)$, and may or may not be linear in the variables (thus, the $\beta$ 's appear with a power of 1 only). For the purpose of this study, linearity meant a regression that was linear in the parameters, thus, the $\beta$ 's appeared with a power of 1 only, and may or may not be linear in the variables. The test for linearity was vital because, the Classical Linear Regression Model (CLRM) needs the association between the response and the predictor variables to be linear (thus, the data should be sampled from a population that relates to the variables of interest in a linear fashion). The Harvey-Collier test for model linearity was employed to examine whether the chosen working models were linear or non-linear. The Harvey-Collier test performs a t-test (with parameter degrees of freedom) on the recursive residuals. If the true relationship is not linear but convex or concave, the mean of the recursive residuals should differ from zero (0) significantly (Harvey \& Collier, 1977). Thus, the Harvey-Collier test, tests the null hypothesis that, a linear specification is correct or a true model is linear (Harvey \& Collier, 1977). 


Table 4: Harvey Collier test for Linearity
\begin{tabular}{|c|c|c|c|}
\hline Model & HC & DF & P-Value \\
\hline ROCE & 0.56623 & 146 & 0.5721 \\
\hline
\end{tabular}

The Harvey Collier test for linearity was conducted on the ROCE model by running the OLS with ROCE as the dependent variable and CFR and $\mathrm{CaR}$ as the independent variables. As displayed in Table 4, the test was not statistically significant at the $5 \%$ level of significance $[(p=0.5721)>0.05]$. The study therefore accepted the null hypothesis that, the ROCE linear specification was linear, and rejected the alternative hypothesis that, the ROCE linear specification was nonlinear. The results show that, the ROCE working model was linear and fit enough to be used for the study.

\subsection{Test for Data Normality}

As posited by Andersen (2012), data non-normality has two important consequences, (1) it poses problems for efficiency-that is, the OLS standard errors are no longer the smallest, and (2) the OLS standard errors can be biased-that is, confidence intervals and significance tests may lead to wrong conclusions. The Shapiro and Wilk (1965) test for data normality was employed for this study. The ShapiroWilk test, tests the null hypothesis that, a sample $X_{1} \ldots \ldots . . . X_{n}$ came from a normally distributed population (Shapiro \& Wilk, 1965; Field, 2009; and Razali \& Wah, 2011). In other words, if the $p$-value is less than the chosen alpha $(\alpha)$ level, then the null hypothesis is rejected and there is evidence that, the data tested is not normally distributed (Shapiro \&
Wilk, 1965; Field, 2009; and Razali \& Wah, 2011). On the other hand, if the $p$-value is greater than the chosen alpha $(\alpha)$ level, then the null hypothesis that, the data came from a normally distributed population cannot be rejected (Shapiro \& Wilk, 1965; Field, 2009; and Razali \& Wah, 2011). As displayed in Table 5, the z-value of ROCE was statistically significant at $\alpha=5 \%[(p=0.00000)<0.05)$. The study therefore failed to accept the null hypothesis that, the data values of ROCE came from a normally distributed population and concluded that, the data values of ROCE were not normally distributed.

The z-value of CFR was also significant at the $5 \%$ significance level $[(p=0.00000)<0.05)$. The study therefore failed to accept the null hypothesis that, the data values of CFR came from a normally distributed population and concluded that, the data values of CFR were not normally distributed. Finally, a z-value of 9.310 with a probability of 0.00000 for $\mathrm{CaR}$ indicated the variable's significance at the $95 \%$ confidence interval. The study therefore failed to accept the null hypothesis that, the data values of CaR came from a normally distributed population and concluded that, the data values of CaR were not normally distributed. From the study's results, all the data values of ROCE, CFR and CaR were not normally distributed at $\alpha=5 \%(p<0.05)$. Hence, a more generalised and robust regression estimator was viewed as ideal for all the data values of the study because, such estimators remedy the issue of data abnormality in classical linear regression analysis.

Table 5: Shapiro-Wilk test for Data Normality

\begin{tabular}{|c|c|c|c|c|c|}
\hline Variable & Obs & W & V & Z & Prob $>$ Z \\
\hline ROCE & 150 & 0.24455 & 87.900 & 10.148 & 0.00000 \\
\hline CFR & 150 & 0.72193 & 32.355 & 7.882 & 0.00000 \\
\hline CaR & 150 & 0.47788 & 60.751 & 9.310 & 0.00000 \\
\hline
\end{tabular}

\subsection{Test for Heteroscedasticity}

According to Greene (2012), Ginker and Lieberman (2017), Giles (2013) and Gujarati and Porter (2009), heteroscedasticity refers to the circumstance in which the variability of a variable is uneven across the range of values of a second variable that predicts it. The Breusch and Pagan (1979) and Cook and Weisberg (1983) test for heteroscedasticity, which tests the null hypothesis of homoscedasticity or the absence of heteroscedasticity in linear regression models, was adopted for this study.

Table 6: Heteroscedasticity Test Results
\begin{tabular}{|c|c|c|}
\hline Model & Chi2 (1) & Prob > Chi2 \\
\hline ROCE & 0.65 & 0.4190 \\
\hline
\end{tabular}

From the Breusch-Pagan and Cook-Weisberg test results shown in Table 6, the chi2 value of 0.65 for the ROCE working model was not statistically significant at $\alpha=5 \%$ $[(p=0.4190)>0.05]$ the $5 \%$ significance level $[(p=0.0000)<0.05]$. The study therefore failed to reject the null hypothesis of the absence of heteroscedasticity among the fitted values of the ROCE working model, and concluded that, there was no heteroscedasticity among the fitted values of the ROCE working model.

\subsection{Test for Serial Correlation}

Verbeek (2012), Colberg and Höfling (2011), Dunn (2005) and Baum (2006) explained serial or autocorrelation as the mathematical representation of the degree of resemblance between a given time series or a cross-section and a lagged version of itself over successive time intervals. In the presence of serial correlation the OLS estimates are no longer the $B L U E$ making room for wrong conclusions or tests of hypothesis (Wooldridge, 2015; Gujarati \& Porter, 2009). The Durbin-Watson test for serial or autocorrelation was adopted for this study. The test, tests the null hypothesis that, the errors are serially uncorrelated as against the alternative hypothesis that, the errors are serially correlated (Durbin \& Watson, 1950; Durbin \& Watson, 1951). The test reports a $d$-statistic with a value from 0 to 4 where; 2 is no autocorrelation, 0 to $<2$ is positive autocorrelation and $>2$ to 4 is negative autocorrelation (Durbin \& Watson, 1950; Durbin \& Watson, 1951).

Table 7: Serial correlation Test Results
\begin{tabular}{|c|c|}
\hline Model & Durbin-Watson d-statistic \\
\hline ROCE & 0.5519247 \\
\hline
\end{tabular}

From Table 7, the study's Durbin-Watson d-statistic value was 0.5519247 . Based on this, the study failed to accept the null hypothesis that, the errors were serially uncorrelated and concluded that, there existed first order positive autocorrelation in the residuals of the ROCE working model. A more generalised and robust regression estimator was therefore viewed as appropriate for estimating the study's working model.

\subsection{Test for Outliers}

As explained by Zimek and Filzmoser (2018), Smith, Martinez and Giraud-Carrier (2014), Zimek, Schubert and 
Kriegel (2012), Jaulin (2010) and Richard (2016), outliers are observation points that are distant from other observations. According to the authors, outliers may be as a result of variabilities in measurements or experimental errors which can pose serious complications in statistical analyses. They may occur by chance in any distribution, but usually indicate either measurement errors or that, a population has a heavy-tailed distribution (Zimek \& Filzmoser, 2018; Smith, Martinez \& Giraud-Carrier, 2014; Jaulin, 2010; and Richard, 2016). One should be concerned about outliers because extreme values of observed variables can distort estimates of regression coefficients, which might lead to wrong conclusions or inferences (Zimek \& Filzmoser, 2018; Smith, Martinez \& Giraud-Carrier, 2014; Jaulin, 2010; and Richard, 2016).

The Nick Cox's outliers detecting technique, which provides perhaps an easier way of identifying the most extreme high and low values of a data set, was employed for this study. By default, the extremes from this technique are the 5 lowest and the 5 highest values of variables under investigation (Cox, 2007; and Smith, Cox \& Bracken, 2011). From the Nick Cox's extremes command, the 5 lowest and the 5 highest extreme values of ROCE, CFR and CaR are as shown in Table 8. Based on the results, it was concluded that, the study's data sample suffered from outlier effects. An estimator that was more robust to outlier effects was therefore viewed as appropriate for data values of this nature.

Table 8: Nick Cox's Extreme Values for ROCE, CFR and

\begin{tabular}{|c|c|c|c|}
\multicolumn{5}{|c|}{ CaR } \\
\hline Obs: & ROCE & CFR & CaR \\
\hline 60. & -1.5666 & -0.1364 & 0.0081 \\
\hline 65. & -0.9059 & 0.0113 & 0.0039 \\
\hline 51. & -0.7763 & 0.0205 & 0.054 \\
\hline 70. & -0.7474 & 0.1389 & 0.0336 \\
\hline 143. & -0.7066 & 1.0273 & 0.5172 \\
\hline 148. & 0.7094 & 0.0727 & 0.1051 \\
\hline 56. & 1.0568 & 0.1748 & 0.1379 \\
\hline 57. & 1.2007 & 0.0807 & 0.1166 \\
\hline 58. & 1.5661 & 0.0133 & 0.1186 \\
\hline 55. & 12.8951 & 0.1479 & 0.0485 \\
\hline \multicolumn{4}{|c}{} \\
\hline
\end{tabular}

\subsection{Model Specification Test}

Model specification involves the selection of the appropriate functional form for a model by choosing which variable(s) to include (Asterious \& Hall, 2011; and Gujarati \& Porter, 2009). Specification errors do sometimes occur when the functional form or the choice of regressors does not coincide with that of the true underlying process, leading to model misspecifications (Asterious \& Hall, 2011; and Gujarati \& Porter, 2009). However, the consequences of model misspecification in regression analysis could be severe in terms of the adverse effects on the sampling properties of both estimators and tests (DeBenedictis \& Giles, 1996). To avoid these severe consequences, the researchers undertook thorough model specification tests. The Durbin-WuHausman test with the null hypothesis of the random effects model being preferable to that of the fixed effects model (Durbin, 1954; Wu, 1973; Hausman, 1978; and Greene, 2012), was adopted to make a choice for the ROCE working model.

Table 9: Model Specification Test Results
\begin{tabular}{|c|c|c|}
\hline Model & Ch2(2) & Prob $>$ Ch2(6) \\
\hline ROCE & 0.37 & 0.8311 \\
\hline
\end{tabular}

From Table 9, the Durbin-Wu-Hausman specification test for the ROCE working model showed a Chi2 of 0.37 which was statistically insignificant at $\alpha=5 \% \quad[\operatorname{ch} 2(2)=0.37$, $(p=0.8311)>0.05]$. The study therefore failed to reject the null hypothesis that, the random effects model was preferred over the fixed effects model and concluded that, the Robust Random effects GLS regression estimator was the best fit for the ROCE working model.

\subsection{Descriptive Analysis of Study Variables}

As shown in Table 10, non-financial firms listed on the Ghana Stock Exchange (GSE) had a mean ROCE of 0.1945633, a standard deviation of 1.09571 and a variance of 1.20058 . This indicates that, the data values of ROCE deviated from both sides of the mean by 1.09571 , implying, the ROCE data values were a bit widely dispersed from the mean. The maximum and minimum values of ROCE were 12.8951 and 1.5666 respectively, leading to a range of 14.4617 . The ROCE distribution was positively skewed with a coefficient of 10.44939. This shows that, the right tail of the ROCE distribution was longer than that of the left tail. Put simply, a large portion of the ROCE distribution fell on the left side of the normal curve. The kurtosis coefficient of 122.057 implies, the ROCE distribution was of abnormal shape.

Table 10: Descriptive Statistics on Study Variables

\begin{tabular}{|c|c|c|c|c|c|c|c|c|c|}
\hline Variable & Obs & Mean & S.D & Variance & Min. & Max. & Range & Skewness & Kurtosis \\
\hline ROCE & 150 & 0.1945633 & 1.09571 & 1.20058 & -1.5666 & 12.8951 & 14.4617 & 10.44939 & 122.057 \\
\hline CFR & 150 & 0.3265207 & 0.7158448 & 0.5124337 & -1.6939 & 4.4039 & 6.0978 & 2.787994 & 15.23229 \\
\hline CaR & 150 & 0.328144 & 0.6793293 & 0.4614883 & 0.0018 & 4.7718 & 4.7700 & 4.029113 & 21.35842 \\
\hline
\end{tabular}

The CFR of the firms had a mean figure of 0.3265207 , a maximum figure of 4.4039 and a minimum figure of -1.6939 , resulting in a range of 6.0978 . The average CFR value of 0.3265207 depicts that, for the period 2008-2017, the firms were not able to generate more cash than what was needed to pay off their current liabilities when they fell due. Put simply, the firms' immediate obligations could not be met by the resources raised from their operations over the period. However, there could be many interpretations for the mean value because, not all low operating cash flow ratios are indications of poor financial health. For instance, the firms might have invested their cash flows into projects that could render greater rewards in the future. The figures 0.7158448 and 0.5124337 being the standard deviation and the variance of CFR respectively indicate that, the data values of CFR were not too dispersed or deviated from the average. The operating cash flow ratio had a skewness value of 2.787994, which is an indication that, the CFR distribution was highly positively skewed or skewed to the right. The kurtosis value of 15.23229 [excess $(K)=15.23229$ $3.0=12.23229]$ for CFR implies, its distribution was of abnormal shape. Finally, CaR of the sampled firms had a mean value of 0.328144 , a standard deviation of 0.6793293 and a variance of 0.4614883 . This implies, the data for $\mathrm{CaR}$ 
deviated from both sides of the mean by 0.6793293 , indicating that, the data values of $\mathrm{CaR}$ were a bit widely dispersed from the mean. The minimum and maximum values of $\mathrm{CaR}$ were 0.0018 and 4.7718 respectively, leading to a range of 4.7700 . The distribution for CaR was highly positively skewed with a coefficient of 4.029113 , whilst the kurtosis coefficient of 21.35842 [excess $(K)=21.35842$ $3.0=18.35842]$ signifies that, the CaR distribution was not normally distributed due to its leptokurtic nature.

\subsection{Regression Analysis}

According to Tofallis (2009), Aldrich (2005), Mogull (2004) and Fotheringham, Brunsdon and Charlton (2002), regression analysis is a set of statistical processes for estimating the relationships among variables. More specifically, regression analysis helps one understand how the typical value of the dependent variable changes when any one of the independent variables is varied, while the other independent variables are held fixed (Tofallis, 2009; Aldrich, 2005; Mogull, 2004; and Fotheringham, Brunsdon \& Charlton, 2002). In order to assess the effect of liquidity on the firms' profitability, the ROCE of the sampled firms was regressed on CFR and CaR. The results are displayed in Table 11 as follows;

Table 11: Robust Random Effects of Liquidity on the Firms' Profitability (ROCE)

\begin{tabular}{|c|c|c|c|c|}
\hline Variable & Coef. $(\boldsymbol{\beta})$ & Robust Std. Err & Z-statistic & Prob(z) \\
\hline CFR & 0.1050416 & 0.0506045 & 2.08 & 0.038 \\
\hline CaR & -0.0805403 & 0.078631 & -1.02 & 0.306 \\
\hline CONS & 0.1866939 & 0.1124316 & 1.66 & 0.097 \\
\hline R-squared: & & Wald chi2(1) & 7.43 & \\
\hline Within & 0.0004 & Prob (chi2) & 0.0244 & \\
\hline Between & 0.0234 & Number of obs & 150 & \\
\hline Overall & 0.0021 & Number of groups & 15 & \\
\hline
\end{tabular}

Note: Regression based on robust estimates according to Huber (1967)/White (1980) as a result of the issues of heteroscedasticity, autocorrelation and outliers detected through the study's diagnostic tests.

As shown in Table 11, CFR had a significantly positive influence on ROCE at the $5 \%$ level of significance $[\beta=0.1050416,(\mathrm{p}=0.038)<0.05]$. The beta $(\beta)$ value of 0.1050416 for CFR implies, on the average, when all other factors were held constant, a unit increase in CFR led to a 0.1050416 increase in ROCE. Cash Ratio (CaR) also had an insignificantly adverse effect on the firms' ROCE at $\alpha=5 \%[\beta=$ $-0.0805403,(p=0.306)>0.05]$. This means, on the average when all other variables were held stationary, a unit increase in CaR did not have any material increase in ROCE. The overall R-squared $\left(R^{2}\right)$ value of 0.0021 depicts that, the explanatory variable accounted for only $0.21 \%$ of the variations in ROCE, whilst the unexplained variations [99.79\% (100-0.21)] were accounted for by other inherent variabilities. The overall $R^{2}$ value was statistically significant at $\alpha=5 \%$. This is substantiated by the Wald chi2(1) value of 7.43 which was significant at the $95 \%$ confidence interval $[(\mathrm{p}=0.0244)<0.05)$. The significance of the $R^{2}$ coefficient is an indication that, the ROCE model satisfied the overall goodness of fit test at $\alpha=5 \%$. The Wald chi2(1) value been significant also portrays that, CFR and CaR had a combined significant effect on the firms' profitability as measured by ROCE. Fitting the coefficients into the ROCE working model, the final model became;

\section{$R O C E=0.1866939+0.1050416 C F R_{i t}-0.0805403 C_{a R_{i t}}(3)$}

\section{DISCUSSIONS AND TESTS OF HYPOTHESIS}

This aspect discusses the study's major findings. The discussions are done in relation to the review of relevant literature and are arranged in the order of; the effect of Cash Flow Ratio (CFR) on the firms' profitability as measured by ROCE; the effect of Cash Ratio (CaR) on the firms' profitability as measured by ROCE; and the effect of Cash Flow Ratio (CFR) and Cash Ratio (CaR) on the firms' profitability as measured by ROCE. Each subdivision concludes with a test of a formulated hypothesis.
5.1. The Effect of Cash Flow Ratio (CFR) on the Firms' Profitability as Measured by ROCE

From the findings, CFR had a significantly positive influence on ROCE at the $5 \%$ level of significance $[\beta=0.1050416$, $(\mathrm{p}=0.038)<0.05]$. This finding supported that of Ofoegbu, Duru and Onodugo (2016) whose study on pharmaceutical companies in Nigeria, provided evidence of liquidity having a significantly positive effect on the firms' financial performance. The finding also supported that of Swagatika and Ajaya (2018) whose research on manufacturing establishments in India, found liquidity as asignificantly positive determinant of the firms' profitability. The finding was further consistent with that of Shaheen, Muhammad, Muhammad, Mudasar and Muhammad (2015) whose study on the Pakistani sugar sector, uncovered liquidity as a significantly positive predictor of the firms' profitability. The finding was again consistent with the prior expectation of the study that $\boldsymbol{\beta}_{\mathbf{1}}>\boldsymbol{0}$. The finding was however not consistent with that of Ashutosh and Gurpreet (2018) whose research on sugar mills in Punjab, India, found liquidity as an insignificant determinant of the profitability of private sugar mills in the Punjab sugar industry. The finding was also not consistent with that of Bilal, Khan, Tufail and Ul Sehar (2013) whose panel study on 31 insurance firms in Pakistan, discovered liquidity as an insignificant determinant of the firms' profitability. The finding finally conflicted that of Rizwan (2016) whose research on 64 non-financial firms listed on the Karachi Stock Exchange (KSE), established liquidity as an insignificant predictor of the firms' financial performance.

\subsubsection{Test of Hypothesis}

From the study's findings, cash flow ratio had a significantly positive impact on the firms' ROCE at $\alpha=5 \%$ [ $\beta=0.1050416$, $(\mathrm{p}=0.038)<0.05]$. The study therefore failed to accept the null hypothesis that the cash flow ratio had no significant influence on the firms' profitability as measured by ROCE, and concluded that the cash flow ratio had a significantly 
positive effect on the firms' profitability as measured by ROCE.

\subsection{The effect of Cash Ratio (CaR) on the Firms' Profitability as Measured by ROCE}

Cash Ratio (CaR) also had an insignificantly negative effect on the firms' ROCE at $\alpha=5 \% \quad[\beta=-0.0805403$, $(\mathrm{p}=0.306)>0.05]$. This finding was in tandem with that of Derbali (2014) whose panel study on eight (8) life insurance companies in Tunisia, uncovered liquidity as an immaterial explanator of the firms' financial performance. The finding was also in line with that of Pratheepan (2014) whose research on 55 manufacturing companies listed on the Colombo Stock Exchange in Sri Lanka, found liquidity as an insignificant predictor of the firms' profitability. The finding further supported that of Batchimeg (2017) whose study on 100 Joint Stock Companies (JSC) listed on the Mongolian Stock Exchange (MSE), discovered liquidity as an insignificant determinant of the firms' financial performance. The finding was however not consistent with that of Ali, Mahmoud, Fadi and Mohammad (2018) whose panel study on listed industrial and service firms in Jordan, established liquidity as a significantly positive influencer of the firms' financial performance.

The finding was also not consistent with that of Hamidah and Muhammad (2018) whose research on 21 companies in Malaysia, found liquidity as a significantly positive predictor of the firms' financial performance. The finding was further inconsistent with that of Maja, Ivica and Marijana (2017) whose dynamic panel study on 956 firms operating in the Croatian food industry, discovered liquidity as a significantly adverse determinant of the firms' performance. The finding was finally inconsistent with the priori expectation of the study that $\boldsymbol{\beta}_{2}>\mathbf{0}$.

\subsubsection{Test of Hypothesis}

From the study's findings, cash ratio had an insignificantly negative effect on the firms' ROCE at $\alpha=5 \%$ [ $\beta=-0.0805403$, $(p=0.306)>0.05]$. The study therefore failed to reject the null hypothesis that cash ratio had no significant influence on the firms' profitability as measured by ROCE, and concluded that cash ratio had an insignificantly adverse effect on the firms' profitability as measured by ROCE.

\subsection{The Effect of Cash Flow Ratio (CFR) and the Cash Ratio (CaR) on the Firms' Profitability as Measured by ROCE}

It was finally discovered from the study that, cash flow ratio and the cash ratio had a combined significant influence on the firms' profitability as measured by ROCE [Wald chi2 $(1)=7.43,(p=0.0244)<0.05]$. This finding is consistent with that of Mehmet and Mehmet (2018) whose research on 10 quoted energy firms in Turkey, found liquidity as a significantly positive determinant of the firms' profitability. The finding is also consistent with that of Isik (2017) whose panel study on 153 real sector firms listed on the Borsa Istanbul Stock Exchange, disclosed liquidity as a significant determinant of the firms' profitability. The finding is further consistent with that of Kanga and Achoki (2017) whose research on agricultural companies listed on the Nairobi Securities Exchange (NSE), uncovered liquidity as a significantly positive predictor of the firms' financial performance. The finding is also in tandem with the priori expectation of the study that $\left(\boldsymbol{\beta}_{\mathbf{1}}, \boldsymbol{\beta}_{2}>\mathbf{0}\right)$ or $\left(\boldsymbol{\beta}_{\mathbf{1}}+\boldsymbol{\beta}_{2} \neq \mathbf{0}\right)$. The finding is however not consistent with that of Mohammed,
Muhammad and Imran (2015) whose research on 99 nonfinancial firms listed on the Saudi Stock Exchange (Tadawul), found liquidity as an insignificant explanator of the firms' profitability. The finding is also inconsistent with that of Gonga and Sasaka (2017) whose study on 55 licensed insurance firms in Nairobi County, discovered liquidity as an insignificant predictor of the firms' financial performance. The finding finally contrasts that of Doğan and Topal (2016) whose pooled OLS regression estimates on 136 Turkish manufacturing firms listed on the Borsa Istanbul Stock Exchange, found liquidity to be weakly related to the firms' financial performance.

\subsubsection{Test of Hypothesis}

From the study's findings, cash flow ratio and the cash ratio had a combined significant influence on the firms' profitability as measured by ROCE [Wald chi2(1) $=7.43$, $(\mathrm{p}=0.0244)<0.05]$. The study therefore failed to accept the null hypothesis that cash flow ratio and the cash ratio had no joint significant influence on the firms' profitability as measured by ROCE, and concluded that, the cash flow ratio and the cash ratio had a combined significant influence on the firms' profitability as measured by ROCE.

\section{Table 12: Summary of the Test Of Hypothesis}

\begin{tabular}{|c|c|c|}
\hline $\begin{array}{c}\text { Hypothesis } \\
H_{1} \text { : Cash flow ratio has a } \\
\text { significant effect on the } \\
\text { firms' profitability as } \\
\text { measured by ROCE. }\end{array}$ & $\begin{array}{c}\text { Analytical } \\
\text { Tool }\end{array}$ & Result \\
$H_{2}$ : Cash ratio has a & & \\
$\begin{array}{c}\text { significant effect on the } \\
\text { firms' profitability as } \\
\text { measured by ROCE. }\end{array}$ & Regression & Rejected \\
$\begin{array}{c}H_{3}: \text { Cash flow ratio and the } \\
\text { cash ratio have a combined } \\
\text { significant effect } \\
\text { on the firms' profitability } \\
\text { as measured by ROCE. }\end{array}$ & Regression & Accepted \\
\hline
\end{tabular}

\section{CONCLUSION AND POLICY IMPLICATIONS}

This study sought to explore the trade-off between liquidity and the profitability of non-financial firms listed on the Ghana Stock Exchange (GSE). Specifically, the study sought to examine the effect of cash flow ratio on the firms' profitability as measured by ROCE; find out the effect of cash ratio on the firms' profitability as measured by ROCE; and to determine the combined effect of cash flow ratio and the cash ratio on the firms' profitability as measured by ROCE. After undertaken some diagnostic and specification tests to address the basic assumptions of the Classical Linear Regression Model (CLRM), the study uncovered that cash flow ratio had a significantly positive effect on the firms' profitability as measured by ROCE $[\beta=0.1050416$, $(p=0.038)<0.05]$, but the cash ratio had an insignificantly negative influence on the firms' profitability as measured by ROCE $[\beta=-0.0805403,(p=0.306)>0.05]$. It was further discovered that the cash flow ratio and the cash ratio had a combined significant effect on the firms' profitability as measured by ROCE [Wald chi2(1)=7.43, $(\mathrm{p}=0.0244)<0.05]$.

The beta $(\beta)$ value for CFR as stated above implies, a unit increase in liquidity led to a 0.1050416 increase in profitability. On the contrary, the coefficient for CaR though immaterial indicates that, a unit increase in liquidity proxied 
by the CaR could lead to a 0.0805403 decrease in the firms' profitability. The underlying issue here is that, the firms do not have to forgo liquidity in order to become profitable. What is required of them is that, they have to strike a balance between the extent at which they can lose liquidity to earn their desired profits, which is the ultimate trade-off between the firms' liquidity and their profitability. In order to ensure continuous survival and success, the firms should not play with the issue of liquidity management. The entities are expected to maintain an optimal liquidity level that will be capable of performing the 'twin' role of meeting their financial obligations and at the same time maximizing their shareholders' wealth. This optimal liquidity level could be obtained if the establishments are to meet the standards set by the Ghana Stock Exchange (GSE). Adhering to these standards will help the firms to reduce the cases of financial distress. In other words, the firms should keep an adequate level of liquidity that will not portend their going concern status, and yet allow them to make ample returns on their investments. Thus, the firms should strike a balance (tradeoff) between their liquidity and profitability. Also, surplus liquidity and inadequate liquidity are two financial ailments that can simply wear down the firms' profitability. Therefore, the establishments must embrace liquidity management in their attempt to optimize profitability. This could be attained if the firms lessen the amounts they hold in cash and focus more on investments so that, they could gain higher returns rather than tying them down in idle cash. From the perspective of theory, the outcome of this study is in tandem with that of prior studies by bringing to light the effect of liquidity on firms' financial performance as measured by return on capital employed. The firms should therefore inculcate into their decisions the findings of this study so as to meet their operational and expansion needs, as well as the desires of their shareholders.

\section{ACKNOWLEDGEMENT}

We duly acknowledge the financial support of the National Natural Science Foundation of China, Grant Award Number 71371087.

\section{REFERENCES}

[1] Abubakar, A., Sulaiman, I., \& Haruna, U. (2018). Effect of firms characteristics on financial performance of listed insurance companies in Nigeria. African Journal of History and Archaeology 3(1), 1-9.

[2] Ajanthan, A. (2013). A nexus between liquidity and profitability: A study of trading companies in Sri Lanka. European Journal of Business and Management, 5(7), 221-237.

[3] Akella, S. (2006). Working capital management in India: In Gopala K.M.G. (2006 Ed.). Toward better working capital management. Punjagutta: The ICFAI University Press.

[4] Aldrich, J. (2005). Fisher and regression. Statistical Science, 20 (4), 401-417.

[5] Ali, M., Mahmoud, A., Fadi, A., \& Mohammad, O. (2018). Factors affecting the corporate performance: Panel data analysis for listed firms in Jordan. Academy of Accounting and Financial Studies Journal, 22(6), 1-10.

[6] Ally, B. (2017). How financially agile are you? Retrieved from https://www.ally.com/do-it-right/money/liquidassets-the-importance-of-financial-liquidity/
[7] Andersen, R. (2012). Advanced Statistics: Diagnostics I: Collinearity, non-normality, and nonconstant error variance, University of Toronto, available at http://individual.utoronto.ca/andersen/

[8] Ashutosh, G., \& Gurpreet, R. (2018). Financial performance of sugar mills in Punjab: A comparative study. Indian Journal of Accounting (IJA), 50 (1), 87-96.

[9] Asteriou, D., \& Hall, S. G. (2011). Misspecification: Wrong regressors, measurement errors and wrong functional forms. Applied Econometrics (2nd ed.). London: Palgrave MacMillan. pp. 172-197.

[10] Ayu, M., Zuraida., \& Mulia, S. (2018). The influence of liquidity, profitability and leverage on profit management and its impact on company value in manufacturing company listed on Indonesia Stock Exchange year 2011-2015. International Journal of Managerial Studies and Research (IJMSR) 6(1), 8-14.

[11] Batchimeg, B. (2017). Financial performance determinants of organizations: The case of Mongolian companies. Journal of Competitiveness, 9(3), 22-33.

[12] Baum, C. F. (2006). An introduction to modern econometrics using STATA. Stata Press.

[13] Ben-Caleb, E., Olubukunola, U., \& Uwuigbe, U. (2013). Liquidity management and profitability of manufacturing companies in Nigeria. IOSR Journal of Business and Management (IOSR-JBM) Vol 9, 13-21.

[14] Bilal, B., Khan, J., Tufail, S., \& Ul Sehar, N. (2013). Determinants of profitability panel data: Evidence from insurance sector of Pakistan. Management and Administrative Sciences Review, 2(1), 10-22.

[15] Black, K. (2010). Business statistics: Contemporary decision making (6th ed.). John Wiley \& Sons.

[16] B Bragg, S. (2018). Liquidity. Retrieved from https://www.accountingtools.com/articles/2017/5/13/liquidi ty

[17] Breusch, T. S., \& Pagan, A. R. (1979). A simple test for heteroskedasticity and random coefficient variation. Econometrica, 47 (5), 1287-1294.

[18] Burke, A. (2019). The definition of liquidity in finance. Retrieved from https://smallbusiness.chron.com/definitionliquidity-finance-36477.html

[19] Colberg, P., \& Höfling, F. (2011). Highly accelerated simulations of glassy dynamics using GPUs: Caveats on limited floating-point precision. Comp. Phys. Comm. 182 (5), 1120-1129.

[20] Cook, R. D., \& Weisberg, S. (1983). Diagnostics for heteroskedasticity in regression. Biometrika 70(1), 110.

[21] Cox, N. J. (2007). Speaking STATA: Turning over a new leaf. Stata Journal, 7, 413-433.

[22] Crossman, A. (2018). Understanding purposive sampling: An overview of the method and its applications. Retrieved from https://www.thoughtco.com/purposive-sampling-3026727.

[23] Damon, V. (2017). How to test linearity in SPSS Retrieved from https://sciencing.com/test-linearityspss-8600862.html 
[24] Dash, M., \& Hanuman, R. (2008). A liquidity-profitability trade-off model for working capital management. Retrieved from http://ssrn.com/abstract=1408722

[25] DeBenedictis, L. F., \& Giles, E. A. D. (1996). Diagnostic testing in econometrics: Variable addition, reset, and Fourier approximations. Retrieved from http://www.uvic.ca/socialsciences/economics/assets/ docs/freset.pdf on $05 / 02 / 2016$

[26] Derbali, A. (2014). Determinants of performance of insurance companies in Tunisia: The case of life insurance. International Journal of Innovation and Applied Studies, 6(1), 90-96.

[27] Doğan, M., \& Topal, Y. (2016). Karlılı̆ğ Belirleyen Finansal Faktörler: BIST’te İşlem Gören İmalat Sanayi Firmaları Üzerine Bir Araştırma. Optimum Ekonomi ve Yönetim Bilimleri Dergisi, 3(1), 55-66.

[28] Dunn, P. F. (2005). Measurement and data analysis for engineering and Science. New York: McGraw-Hill.

[29] Durbin, J. (1954). Errors in variables. Review of the International Statistical Institute, 22 (1/3), 23-32.

[30] Durbin, J., \& Watson, G. S. (1950). Testing for serial correlation in least squares regression, I. Biometrika, 37(3- 4), 409-428.

[31] Durbin, J., \& Watson, G. S. (1951). Testing for serial correlation in least squares regression, II. Biometrika, 38(1- 2), 159-179.

[32] Ejike, S. I., \& Agha, N. C. (2018). Impact of operating liquidity on profitability of pharmaceutical firms in Nigeria. International Journal of Academic Research in Accounting, Finance and Management Sciences, 8(3), 73-82.

[33] Evans, L. C. (2010). Partial differential equations, Graduate studies in mathematics, 19 (2nd ed.). Providence, R. I.: American Mathematical Society.

[34] Field, A. (2009). Discovering statistics using SPSS (3rd ed.). Los Angeles [i.e. Thousand Oaks, Calif.]: SAGE Publications. p. 143. ISBN 978-1-84787-906-6.

[35] Fotheringham, A. S., Brunsdon, C., \& Charlton, M.(2002). Geographically weighted regression: The analysis of spatially varying relationships (Reprint ed.). Chichester, England: John Wiley.

[36] Garcia, T. P. J., \& Martinez, S. P. (2007). Effects of working capital management on SME profitability. International Journal of Managerial Finance 3(2), 164177.

[37] Giles, D. (2013). Robust standard errors for nonlinear models. Econometrics Beat.

[38] Ginker, T., \& Lieberman, O. (2017). Robustness of binary choice models to conditional heteroscedasticity. Economics Letters, 150, 130-134.

[39] Gonga, M. A., \& Sasaka, P. S. (2017). Determinants of financial performance of insurance firms: A survey of selected insurance firms in Nairobi County. The Strategic Journal of Business \& Change Management, 4(4), pp.123-145.

[40] Greene, W. H. (2012). Estimation and inference in binary choice models. Econometric analysis (Seventh ed.). Boston: Pearson Education, pp. 730-755.
[41] Gujarati, D. N., \& Porter, D. C. (2009). Econometric modeling: Model specification and diagnostic testing. Basic econometrics (fifth ed.). New York: McGraw-Hill Irwin. pp. 467-522.

[42] Hair, J. F., Black, W. C., Babin, B. J., \& Anderson, R. E. (2013). Multivariate data Analysis. Pearson Education, Limited.

[43] Hamidah, R., \& Muhammad, K. H. B. N. (2018). The effect leverage, liquidity and profitability on the companies performance in Malaysia. Journal of Humanities, Language, Culture and Business (HLCB), 2(7), 9-15.

[44] Hari, M. (2011). Why do hypothesis testing? Retrieved from https://www.knowswhy.com/why-do-hypothesistesting/

[45] Harvey, A., \& Collier, P. (1977). Testing for functional misspecification in regression analysis. Journal of Econometrics, 6, 103-119.

[46] Hausman, J. A. (1978). Specification tests in econometrics. Econometrica, 46(6), 1251-1271.

[47] Huber, P. J. (1967). The behavior of maximum likelihood estimates under nonstandard conditions. Paper presented at the proceedings of the fifth Berkeley symposium on mathematical statistics and probability.

[48] Isik, 0. (2017). Determinants of profitability: Evidence from real sector firms listed in Borsa Istanbul. Business and Economics Research Journal (BERJ), 8(4), 689-698.

[49] Jaulin, L. (2010). Probabilistic set-membership approach for robust regression (PDF). Journal of Statistical Theory and Practice, 4, 155-167.

[50] Kanga, O.S., \& Achoki, G. (2017). Liquidity and Financial Performance in Agricultural Firms listed in the Nairobi Securities Exchange in Kenya. International Journal of Business and Social Science, 7(7), 57-65.

[51] Kenton, W. (2018). Multicollinearity. Retrieved from www.investopedia.com/terms $/ \mathrm{m} /$ multicollinearity.asp

[52] Kesseven, P. (2006). Trends in working capital management and its impact on firms' performance. International Review of Business Research Papers, 2(2), 45-58.

[53] Kock, N., \& Lynn, G. S. (2012). Lateral collinearity and misleading results in variance-based SEM: An illustration and recommendations (PDF). Journal of the Association for Information Systems, 13 (7), 546-580.

[54] Kohler, U., \& Kreuter, F. (2008). Datenanalyse mit stata: Allegemeine Konzepte der Datenanalyse und ihre praktische Anwendung: Oldenbourg.

[55] Kolts, B. S. (2005). Understanding linearity and monotonicity. Foreign Electronic Measurement Technology, 24 (5), 30-31.

[56] Kostohryz, J. (2013). Why stocks are rising: It's the liquidity, stupid! Yahoo Finance. Retrieved from https://finance.yahoo.com/news/why-stocks-risingliquidity-stupid-100000868.html

[57] Lamberg, S., \& Valming, S. (2009). Impact of liquidity management on profitability: A study of the adaptation of liquidity strategies in financial crisis. UMEA University Master Thesis, Spring Semester 2009, OneYear, 15hp. 
[58] Lazaridis, I., \& Tryfonidis, D. (2005). The relationship between working capital management and profitability of listed companies on the Athens Stock Exchange. Retrieved from http://papers.ssrn.com/so13/papers.cfm?abstractid=931591

[59] Lyndon, M. E., \& Paymaster, F. B. (2016). Liquidity management and profitability: A study of selected food and beverage companies in Nigeria. International Journal of Management Sciences, 7(4), 217-225.

[60] Maja, P., Ivica, P., \& Marijana, Ć., (2017). The influence of age on firm performance: Evidence from the Croatian Food Industry. Journal of Eastern Europe Research in Business and Economics, Vol. 2017 (2017), DOI: 10.5171/2017.618681,http://www.ibimapublishing.com/j ournals/JEERBE/jeerbe.html

[61] Mehmet, A., \& Mehmet, İ. (2018). Determining the impact of financial characteristics on firm profitability: An empirical analysis on Borsa Istanbul Energy Firms. WSEAS Transactions on Business and Economics, Vol. 15, 2018, 547-559.

[62] Moffatt, M. (2017). Liquidity-dictionary definition of liquidity. About.com Education. Retrieved from https://www.thoughtco.com/definition-of-liquidity-1146123

[63] Mogull, R. G. (2004). Second-semester applied statistics. Kendall/Hunt Publishing Company. p. 59. ISBN 978-07575-1181-3.

[64] Mohammed, Z. R., Muhammad, N. K., \& Imran, K. (2015). Investigating liquidity-profitability relationship: Evidence from companies listed in Saudi Stock Exchange (Tadawul). Journal of Applied Finance \& Banking, 5(3), 159-173.

[65] Mohd, Y., \& Asif, P. (2018). Impact of liquidity, solvency and efficiency on profitability of steel authority of India limited. International Journal of Research in Management, Economics and Commerce 06(09), 25-31.

[66] Mueller, J. (2018). Understanding financial liquidity. Retrieved

from https://www.investopedia.com/articles/basics/07/liquidity.a sp\#ixzz5WdDY41rG

[67] Niresh, J. A. (2012). Trade-off between liquidity \& profitability: A study of selected manufacturing firms in Sri Lanka. ResearchersWorld-Journal of Arts, Science \& Commerce, Vol. III, Issue 4(2), 34-40.

[68] O'Brien, R. M. (2007). A caution regarding rules of thumb for variance inflation factors. Quality \& Quantity, 41(5), 673.

[69] Ofoegbu, N. G., Duru, N. A., \& Onodugo, V. (2016). Liquidity management and profit performance of pharmaceutical manufacturing firms listed in Nigeria Stock Exchange. International Journal of Management Sciences and Business Research, 5(7), 1-13.

[70] Olagunju, A., Adeyanju, O. D., \& Olabode, O. S. (2011). Liquidity management and commercial banks' profitability in Nigeria. Research Journal of Finance and Accounting, 2(7/8), 24-38.

[71] Onyekwelu, U. L., Chukwuani, V. N., \& Onyeka, V. N. (2018). Effect of liquidity on financial performance of deposit money banks in Nigeria. Journal of Economics and Sustainable Development 9(4), 19-28.

[72] Orshi, T. S. (2016). Impact of liquidity management on the financial performance of listed food and beverages companies in Nigeria. Published Thesis, Federal University Dutsin-Ma.

[73] Panigrahi, A. K. (2013). Liquidity management of Indian cement companies: A comparative study. IOSR Journal of Business and Management, 14(5), 49-61.

[74] Patricia, M. S., \& Hassan, T. (2006). Intermediate theory: The missing link in successful student scholarship. Journal of Public Affairs Education, 12(3), 13-334.

[75] Patricia, M. S., \& Nandhini, R. (2013). A playbook for research methods: Integrating conceptual frameworks and project management. Stillwater, OK: New Forums Press. pp. 109-157

[76] Peavler, R. (2017). Analysis of liquidity position using financial ratios. Retrieved from https://www.thebalancesmb.com/liquidity-positionanalysis-with-ratios-393233

[77] Pratheepan, T. (2014). A panel data analysis of profitability determinants: Empirical results from Sri Lankan manufacturing companies. International Journal of Economics, Commerce and Management, 2(12), 1-9.

[78] Puneet, S., \& Parmil, K. (2012). Liquidity and profitability trade-off. International Journal of Advanced Research in Management and Social Science, 1(3), 77 84.

[79] Raheman, A., \& Nasr, N. (2007). Working capital management and profitability-A case of Pakistani firms. International Review of Business Research Papers, 3(1), 279-300.

[80] Raykov, E. (2017). The liquidity-profitability trade-off in Bulgaria in terms of the changed financial management functions during crisis. Management, 22(1), 135-156.

[81] Razali, N., \& Wah, Y. B. (2011). Power comparisons of Shapiro-Wilk, Kolmogorov-Smirnov, Lilliefors and Anderson-Darling tests. Journal of Statistical Modeling and Analytics, 2(1), 21-33.

[82] Richard, W. (2016). Outliers. University of Notre Dame. Retrieved from https://www3.nd.edu/ rwilliam/

[83] Rizwan, I. (2016). Impact of liquidity management on profitability of Pakistani firms: A case of KSE-100 Index. International Journal of Innovation and Applied Studies, 14(2), 304-314.

[84] Saluja, P., \& Kumar, P. (2012). Liquidity and profitability trade-off: A study on Airtel Bharti limited. International Journal of Advanced Research in Management and Social Sciences, 1(3), 77-84.

[85] Samiloglu, F., \& Demirgunes, K. (2008). The effect of working capital management on firm profitability: Evidence from Turkey. International Journal of Applied Economics and Finance, 2(1), 44-50.

[86] Sandhar, S. K., \& Janglani, S. (2013). A study on liquidity and profitability of selected Indian cement companies: A regression modelling approach. International Journal of Economics, Commerce and Management, UK, 1(1), 1-24. 
International Journal of Trend in Scientific Research and Development (IJTSRD) @ www.ijtsrd.com eISSN: 2456-6470

[87] Saunders, M., Lewis, P., \& Thornhill, A. (2012). Research methods for business students (6th edition). Pearson Education Limited.

[88] Schick, T., \& Vaughn, L. (2002). How to think about weird things: Critical thinking for a New Age. Boston: McGraw-Hill Higher Education. ISBN 0-7674-2048-9.

[89] Shaheen, A., Muhammad, I., Muhammad, R., Mudasar, A., \& Muhammad, A. (2015). Impact of liquidity on profitability in sugar sector of Pakistan. Research Journal of Finance and Accounting, 6(15), 10-19.

[90] Shapiro, S. S., \& Wilk, M. B. (1965). An analysis of variance test for normality (complete samples). Biometrika, 52 (3-4), 591-611.

[91] Smith, M. R., T. Martinez., \& Giraud-Carrier, C. (2014). An instance level analysis of data complexity. Machine Learning, 95(2), 225-256.

[92] Smith, M. W., Cox. N. J., \& Bracken, L. J. (2011). Modeling depth distributions of overland flows. Geomorphology, $125,402-413$.

[93] Stewart, J. (2008). Calculus: Early transcendentals (6th ed.). Brooks Cole Cengage Learning.

[94] Swagatika, N., \& Ajaya, K. P. (2018). The determinants of corporate profitability: An investigation of Indian manufacturing firms. International Journal of Emerging Markets, 13(1), 66-86.

[95] Syed, A. (2015). Impact of liquidity and management efficiency on profitability: An empirical study of selected power distribution utilities in India. Journal of Entrepreneurship, Business and Economics 3(1), 31-49.

[96] Tofallis, C. (2009). Least squares percentage regression. Journal of Modern Applied Statistical Methods, 7, 526534.

[97] Torres-Reynia, O. (2007). Panel data analysis: Fixed and random effects using STATA, Princeton University.

[98] Verbeek, M. (2012). A guide to modern econometrics (fourth ed.). Chichester: John Wiley. pp. 112-116.

[99] White, H. (1980). A heteroskedasticity-consistent covariance matrix estimator and a direct test for heteroskedasticity. Econometrica, 48 (4), 817-838.

[100] Wooldridge, J. M. (2015). Business \& economics. Retrieved https://books.google.com/books?isbn=1305446380

[101] Wu, D., (1973). Alternative tests of independence between stochastic regressors and disturbances. Econometrica, 41(4), 733-750.

[102] Zimek, A., \& Filzmoser, P. (2018). There and back again: Outlier detection between statistical reasoning and data mining algorithms. Wiley Interdisciplinary Reviews: Data Mining and Knowledge Discovery, 8 (6), e1280.

[103] Zimek, A., Schubert, E., \& Kriegel, H. P. (2012). A survey on unsupervised outlier detection in high-dimensional numerical data. Statistical Analysis and Data Mining, 5(5), 363-387. 